\title{
Comparing the Contribution of Vocabulary Breadth to IELTS and TOEFL Reading Subtests
}

\author{
Is'HAAQ AKBARIAN \\ University of Qom, Qom, Iran \\ Seyyed Mohammad Alavi \\ University of Tehran, Tehran, Iran
}

Received: 18 December 2011 / Accepted: 3 November 2012

ISSN: 1697-7467

\begin{abstract}
This research investigates whether there is any significant difference between the predictive power of vocabulary breadth and the reading subtests of IELTS and TOEFL. Iranian EFL participants (223) answered Vocabulary Levels Test (VLT), sample IELTS and TOEFL reading subtests. Linear regression analysis results show that VLT provides a significant amount of prediction on IELTS and TOEFL reading subtest, $\mathrm{R}^{2}=0.274,0.298$, respectively. The results for the participants with different levels of vocabulary knowledge, based on VLT percentile scores, show that, for low group, VLT provides $0.123 \%$ prediction for IELTS reading subtest and nothing for TOEFL reading subtest. For middle group, VLT provides no prediction on IELTS and TOEFL reading subtest. For high group, the amount of prediction provided on IELTS reading subtest is 0.130 and that on TOEFL is 0.209 . Also, analysis was conducted to determine the most related variable to VLT. The results show that TOEFL reading subtest is more associated with vocabulary breadth than IELTS. The study discusses a few implications.

Keywords: Vocabulary breadth; Predictive power; IELTS reading subtest; TOEFL reading subtest; EFL learners.
\end{abstract}

Comparación de la aportación de la riqueza léxica en la realización de las pruebas de lectura del IELTS y TOEFL

RESUMEN: Esta investigación intenta determinar si existe alguna diferencia significativa entre el poder predictivo de la riqueza léxica y las pruebas de lectura de IELTS (International English Language Testing System) y TOEFL (Test of English as a Foreing Language). Los participantes son alumnos iraníes de inglés lengua extranjera (223) y realizaron varias pruebas: una prueba de nivel de vocabulario (PNV), y modelos de los exámenes IELTS y TOEFL de lectura. Los resultados del análisis de la regresión lineal muestran que PNV dota de un alto grado de predicción en las pruebas de lectura de IELTS y TOEFL, $\mathrm{R}^{2}=0.274,0.298$, respectivamente. Los resultados de los participantes con diferentes niveles de manejo léxico, basados en las puntuaciones de PNV en percentiles, demuestran que para el grupo inferior, el PNV dota de una predicción de $0.123 \%$ para la prueba de lectura del IELTS y ninguna para la del TOEFL. El PNV no ofrece ningún tipo de predicción para ambas pruebas en el grupo medio. Para el grupo superior, la predicción que es posible determinar en la prueba de lectura del IELTS es 0.130 y en la del TOEFL 0.209. También a través del análisis se ha intentado determinar la variable más relacionada con PNV. Los resultados muestran que la prueba de lectura 
del TOEFL está más asociada a la riqueza léxica que la prueba del IELTS. Además se ha reflexionado sobre las consecuencias de los datos obtenidos.

Palabras clave: riqueza léxica; poder predictivo; prueba de lectura IELTS; prueba de lectura TOEFL; estudiantes de inglés lengua extranjera.

\section{INTRODUCTION}

Vocabulary knowledge is no longer regarded as the Cinderella of language learning and teaching. Yet, Milton et al. (2008) indicate that fresh vocabulary research can still provide some contributions to the practice of language pedagogy. These researchers talk about several direct ways in which vocabulary research can contribute to the task of teaching and learning languages. Vocabulary research, according to Milton et al. (2008: 123-137), can help us (a) understand "how language is constructed, how it is learned, and how it is used in communication", (b) "establish norms of progress and even standards of knowledge and performance", (c) "understand and control language input", and (d) select "appropriate methodologies and techniques to enhance progress and performance" of language learners. These potential roles of vocabulary research, as Akbarian (2010) suggests, might be the reason why researchers are motivated to investigate vocabulary from different novel perspectives.

Though there are many studies conducted on the relation hip between vocabulary knowledge and different aspects of language proficiency, there is still an absence of studies exploring the extent to which vocabulary size contributes to the different language skills... (Stæhr, 2008: 139) and sub-skills (Alavi \& Akbarian, 2012). More particularly, few studies try to link vocabulary breadth to high-stakes examinations, such as IELTS (Milton, 2009). As a matter of fact, Milton's (2009) volume which is an update on issues in assessing vocabulary does not report any investigation exploring the comparative contribution of vocabulary breadth to the reading section of IELTS and TOEFL in foreign language situations. Given that, the current research reports the results of an empirical study, addressing the extent to which the size or breadth of vocabulary knowledge is associated with the reading subtests of these two widely used proficiency tests.

\section{Review OF The Literature}

Apparently, the association between vocabulary breadth and reading comprehension has been explored from two perspectives in the literature: Firstly, this issue is linked with the question of how many words in a text a language learner needs to know so as to comprehend that text adequately (Stæhr, 2008). Secondly, more empirical investigations have been reported on finding the mere relationship between vocabulary breadth and reading comprehension or skill. In essence, the studies on vocabulary breadth and reading skill exceed those related to the other skills.

In accordance with the first line of research, $\mathrm{Hu}$ and Nation (2000) examined the relationship between text coverage, i.e. the percentage of running known words in the text, and reading comprehension for non-native speakers of English. The researchers showed that $98 \%$ text coverage ( 1 unknown word in 50 ) would be needed for most learners to comprehend a fiction text adequately. 
Is`hata Akbarian and Seyyed Mohammad Alavi Comparing the Contribution of Vocabulary...

Also, on the basis of the British National Corpus, Nation (2006) conducted a trialling of 14 most frequent 1,000 word-family lists and used them to detect what vocabulary breadth would be needed for unassisted comprehension of written and spoken English. Taking a lexical coverage of $98 \%$ of any text as the ideal coverage for unassisted comprehension, Nation states that a 8,000 to 9,000 word-family vocabulary is needed for comprehension of written text and a vocabulary of 6,000 to 7,000 for spoken text(p. 59).

In line with the second perspective, more researches have been reported. For instance, Qian (1999) carried out an investigation on the relationship between vocabulary breadth, vocabulary depth, and reading comprehension of Chinese and Korean English learners. His results displayed high inter-correlations between these variables, ranging from 0.78 to 0.82. As a follow-up to this study, Qian (2002) conducted another study to conceptually validate the roles of breadth and depth of vocabulary knowledge in reading comprehension in academic settings using a heterogeneous sample of mixed first language backgrounds. He used a refined version of the depth-of-vocabulary-knowledge (DVK) test of Read (1995), reading for basic comprehension measure (TOEFL-RBC), a vocabulary size (VS) measure developed by Nation (1983), and a TOEFL vocabulary measure (VM). Qian showed that there were high inter-correlations between the scores on the DVK, VS, TOEFL VM, and TOEFL-RBC. A strong significant correlation was displayed between VS test and TOEFL$\mathrm{RBC}(\mathrm{r}=0.74, \mathrm{p}<0.01)$.

Administering Vocabulary Levels Test (VLT), the Productive Version of the VLT, and a TOEFL test to 76 Iranian undergraduate students, Golkar and Yamini (2007) examined the relationship between active and passive vocabulary knowledge, and the learners' proficiency level and reading comprehension ability. What is significant to our interest is that vocabulary size turned out to have a high and significant correlation with both proficiency levels and the reading comprehension ability. The correlation between their passive and active vocabularies and reading comprehension ability produced a coefficient of 0.75 and 0.80 , respectively, with active vocabulary showing a higher index. The researchers attribute it to the fact that "passive knowledge takes much practice and experience in language to turn into active", and conclude that language learners "with a higher active vocabulary have had a higher amount of practice in reading texts, too; hence their better reading comprehension ability" (p. 101).

In a recent study, Zhang and Anual (2008) explored the role of vocabulary knowledge in reading comprehension with 37 year-4 secondary students in Singapore. They used VLT to measure students' vocabulary knowledge in relation to the different measures, i.e. short answer questions and summary task, intended to test their reading comprehension. Vocabulary knowledge at the 2,000-word level and reading comprehension significantly ( $r=0.423, p$ $<0.01$ ) correlated together, while at the 3,000-word level, a strong significant correlation was produced for the short-answer questions $(r=0.848, p<0.01)$. At the 5,000-word level, the correlation was not significant for the short-answer questions. However, no significant correlation was displayed for the summary task at any level. For this, the researchers suspect that different task formats might have affected comprehension performance.

Stæhr (2008) investigated the relationship between vocabulary breadth and the reading skill, in addition to writing and listening of Danish learners of English from lower secondary education whose language skills were assessed as part of the national school leaving examination. Vocabulary size displayed a high correlation of $0.83(\mathrm{p}<.01)$ with reading comprehension, thus indicating the reading skill to be the most dependent on vocabulary size in that study. The researcher further found that the participants, knowing the most frequent 
2,000 word families, obtained a score above average on reading and the other two skills, while for those not mastering the most frequent 2,000 word families, "the picture was less clear" (Stæhr, 2008: 149).

Whereas there are several investigations using the reading section of TOEFL, researchers have not conducted any studies, other than Milton, Wade, and Hopkins (2010), to correlate vocabulary breadth with the reading section of IELTS or to compare the importance of vocabulary breadth in these two widely used tests.

Using 30 EFL learners as participants, Milton, et al. (2010) correlated two receptive vocabulary size measures, the X_Lex (Meara \& Milton, 2003) and the A_Lex (Milton \& Hopkins, 2005), with the IELTS test. They used Spearman correlations, producing a significant coefficient of .699 for the relationship between vocabulary size (the X_Lex) and the reading component of IELTS. Actually, vocabulary size explains nearly 50 per cent of the variance in the reading scores of IELTS.

A closer examination of the studies, in which the role of vocabulary in reading comprehension was investigated, shows that there is still paucity of research in the field. Since, an understanding of this relationship is quite essential to the field and in language education, this study is an attempt to fill this particular gap.

\subsection{Research question}

The present study aimed to investigate the role of vocabulary breadth for reading comprehension in two widely-used proficiency tests, i.e. TOEFL and IELTS reading subtests. To this end, the following research question guided this investigation:

Is there any significant difference between the predictive power of vocabulary breadth and the reading subtests of IELTS and TOEFL?

\section{3. МетноD}

\subsection{Participants}

There were 202 participating EFL students on IELTS and 223 on TOEFL from different Iranian universities. They ranged from BA sophomores studying English literature to MA students studying TEFL (Table 1). VLT was used to classify the participants into three groups with different vocabulary proficiency levels. Classifying the participants into three groups was based on their percentile rank in the scores on VLT (discussed later). Experience shows that sometimes degree does not show EFL learners' vocabulary knowledge level.

Table 1. Profile of the Participants.

\begin{tabular}{c|cc|cc|c}
\hline \multicolumn{1}{c}{ Test } & \multicolumn{3}{c}{ Male } & \multicolumn{2}{c}{ Female } \\
& Undergraduate & Graduate & Undergraduate & Graduate & \\
\hline IELTS & 64 & 16 & 99 & 23 & 202 \\
\hline TOEFL & 83 & 14 & 103 & 23 & 223 \\
\hline
\end{tabular}


Is`hata Akbarian and Seyyed Mohammad Alavi Comparing the Contribution of Vocabulary...

\subsection{Materials}

To conduct this research, three tests were employed. They are Vocabulary Levels Test (VLT), the reading section of IELTS containing 40 items, and the reading section of TOEFL consisting of 50 items.

\subsubsection{Vocabulary Levels Test (VLT)}

Version 2 of VLT, revised and validated by Schmitt, Schmitt, and Clapham (2001), was used in this study. According to Nation (1990), the vocabulary of English (and indeed any language) can be viewed as consisting of a series of levels based on frequency of occurrence. The levels contain groups of 1,000 words. So VLT measures knowledge of words at five levels: $2,000,3,000,5,000,10,000$, and Academic Vocabulary section that is not used since it is different in kind from the other levels and should not be included in the profile comparison (Schmitt et al., 2001). At each level, there are 10 three-item clusters (i.e., 30 items). Twenty four correct answers at a level is the criterion for its mastery (N. Schmitt, personal communication, May 9, 2008). With 88 participants, Stæhr (2008) calculated the Cronbach's alpha of this version of VLT at 0.96. Interestingly enough, in the current study, Cronbach's alpha on VLT at the four 1,000-, 3,000-, 5,000-, and 10,000-word frequency levels was also calculated at 0.963 . The following is an example:

1 business
2 clock
3 horse
4 pencil
5 shoe
6 wall

- part of a house

- animal with four legs

_ something used for writing

\subsubsection{IELTS Reading Subtest}

Lynda Taylor, an authority in the field, recommended the use of published practice materials (L. Taylor, personal communication, November 6, 2006) since live versions of IELTS reading are not released for research purposes. Given that, past exam papers from the reading section of Test 1, Cambridge IELTS 5 (2006: 16 28), were used.

In this study, Academic Reading module was used. This module consists of three sections containing passages (with a total of 2,000 to 2,750 words), taken from magazines, journals, books, and newspapers. At least one passage contains detailed logical argument.

\subsubsection{TOEFL Reading Subtest}

Genuine running TOEFL is not released either. Official practice tests and TOEFL actual tests (administered in the past by ETS) have been published. Therefore, the (pBT) reading section of January 2004 version (TOEFL ACTUAL TESTS, 2005: 25 35) was used for the sake of reliability and the lack of technological facilities in our context for iBT versions. 
TOEFL reading subtest includes several passages (here five) with multiple-choice questions, between 250 and 350 words long, taken from college-level textbooks used in introductions to a discipline or topic.

It is worth noting here that the reference to IELTS and TOEFL reading subtests throughout the current study is to a sample of IELTS and TOEFL tests used in Iran, not the real IELTS and TOEFL test.

\subsection{Procedures and data analyses}

Willing and generous to respond, and informed of the purpose of the tests for research purposes, the participants answered the tests in separate sessions in the following order: VLT (30 $\mathrm{min})$, TOEFL reading subtest $(55 \mathrm{~min})$, and IELTS reading subtest $(60 \mathrm{~min})$.

The tests were administered in non-class periods. As a result, out of the original pool of 296 participants answering VLT, not all of them were able to respond to all the above instruments; some did not turn up in the session on TOEFL or IELTS for personal problems while some were unwilling to continue after answering VLT. Still, some others were unable to answer all the items on TOEFL and IELTS in due time. Therefore, they were excluded from the analysis, too.

VLT was regarded as the independent variable and IELTS and TOEFL were taken as the dependent variables in their respective analyses. Linear regression analysis was performed to investigate the predictive power of vocabulary knowledge on the reading subtest of IELTS and TOEFL. To delve into the issue further, a series of linear regression analyses were conducted on the data to report the predictive values of vocabulary knowledge in IELTS and TOEFL reading subtests with regard to the overall performance of the participants on VLT and their performance on the four levels of word frequency bands (i.e., across levels). At this stage, the grouping into vocabulary proficiency levels was done based on the participants' percentile rank for the scores they obtained on VLT. The overall alpha significance level was preset at $p<.05$ for all the analyses.

\section{RESUlts}

The research question aims to answer whether there is any significant difference between the predictive power of vocabulary breadth and the reading subtest of IELTS and TOEFL, in answer to which the participants are first considered as one group, irrespective of the difference in their level among them, and then divided into three groups. Moreover, since there is difference in the number of the participants on IELTS and TOEFL, the study separately presents the results in the order of IELTS, TOEFL, and the comparison between these two tests.

With respect to the overall performance of the participants on VLT as one composite variable, the descriptive statistics in Table 2 and 3 provide a general profile of the participants' performance. 
Is `haAq Akbarian and Seyyed Mohammad Alavi Comparing the Contribution of Vocabulary...

Table 2. Descriptive Statistics for the Reading Subtest of IELTS and VLT.

\begin{tabular}{ccccc}
\hline & MPS & Mean & Std. Deviation & N \\
\hline IELTS reading subtest & 40 & 22.63 & 6.19 & 202 \\
\hline VLT & 120 & 76.79 & 16.54 & 202 \\
\hline
\end{tabular}

Note: MPS = Maximum Possible Score

Table 3. Descriptive Statistics for the Reading Subtest of TOEFL and VLT.

\begin{tabular}{ccccc}
\hline & MPS & Mean & Std. Deviation & N \\
\hline TOEFL reading subtest & 50 & 30.58 & 8.93 & 223 \\
\hline VLT & 120 & 76.68 & 16.42 & 223 \\
\hline
\end{tabular}

Note: $M P S=$ Maximum Possible Score

Simple or linear regression analysis was conducted to determine the predictive power of vocabulary knowledge, as captured in VLT, on IELTS reading subtest. The results illustrated in Table 4 show a moderate positive correlation between the two variables, VLT and the reading subtest of IELTS. In the table of model summary for VLT and IELTS reading subtest $\mathrm{R}=0.524, \mathrm{R}^{2}=0.271$. This suggests that VLT and the reading subtest of IELTS actually overlap one another to some extent: VLT has $27 \%$ explained variance in the reading subsection of IELTS.

Table 4. Model Summary for VLT and IELTS Reading Subtest.

\begin{tabular}{cccccccccc}
\hline & & & & & & \multicolumn{5}{c}{ Change Statistics } \\
\cline { 5 - 9 } Model & $\mathbf{R}$ & $\begin{array}{c}\text { R } \\
\text { Square }\end{array}$ & $\begin{array}{c}\text { Adjusted } \\
\text { R Square }\end{array}$ & $\begin{array}{c}\text { Std. Error } \\
\text { of the } \\
\text { Estimate }\end{array}$ & $\begin{array}{c}\text { R } \\
\text { Square } \\
\text { Change }\end{array}$ & $\begin{array}{c}\text { F } \\
\text { Change }\end{array}$ & Df1 & df2 & $\begin{array}{c}\text { Sig. F } \\
\text { Change }\end{array}$ \\
\hline 1 & $0.524^{\mathrm{a}}$ & 0.274 & 0.271 & 5.28243 & 0.274 & 75.619 & 1 & 200 & 0.000 \\
\hline
\end{tabular}

a. Predictors: (Constant), VLT

b. Dependent Variable: IELTS reading subtest

To illustrate the percentage of increase in the independent variable and the resultant change in the dependent variable, Table 5 shows that we obtained $a=7.591$ for the intercept and $b=0.196$ for the slope. So, given the data, for each percentage of increase in VLT scores, the scores on the reading subsection of IELTS change $b(0.196)$ units. 
Table 5. Coefficients.

\begin{tabular}{ccccccc}
\hline \multirow{2}{*}{ Model } & \multicolumn{2}{c}{$\begin{array}{c}\text { Unstandardized } \\
\text { Coefficients }\end{array}$} & $\begin{array}{c}\text { Standardized } \\
\text { Coefficients }\end{array}$ & t & Sig. \\
\cline { 3 - 5 } & & B & Std. Error & Beta & & \\
\hline \multirow{2}{*}{1} & (Constant) & 7.591 & 1.769 & & 4.290 & 0.000 \\
& VLT & 0.196 & 0.023 & 0.524 & 8.696 & 0.000 \\
\hline
\end{tabular}

a. Predictors: (Constant), VLT

b. Dependent Variable: IELTS reading subtest

Similarly, linear regression analysis was used to analyze the data collected on TOEFL reading subtest. As Table 6 shows, a moderate positive correlation exists between the two variables of VLT and the reading subtest of TOEFL. That is, $\mathrm{R}=0.546$. The index seems to be slightly higher than that of IELTS above. The corresponding coefficient of determination (adjusted $\mathrm{R}^{2}$ ), resulting from Pearson correlation coefficient, is considerable: $\mathrm{R}^{2}=$ 0.295. Likewise, it suggests that VLT and the reading subtest of TOEFL actually overlap one another to some extent: VLT can explain approximately $30 \%$ of the variance in the reading subsection of TOEFL.

Table 6. Model Summary for VLT and TOEFL Reading Subtest.

\begin{tabular}{|c|c|c|c|c|c|c|c|c|c|}
\hline \multirow{2}{*}{ Model } & \multirow{2}{*}{$\mathbf{R}$} & \multirow{2}{*}{$\begin{array}{c}\text { R } \\
\text { Square }\end{array}$} & \multirow{2}{*}{$\begin{array}{l}\text { Adjusted } \\
\text { R Square }\end{array}$} & \multirow{2}{*}{$\begin{array}{l}\text { Std. Error } \\
\text { of the } \\
\text { Estimate }\end{array}$} & \multicolumn{5}{|c|}{ Change Statistics } \\
\hline & & & & & $\begin{array}{l}\text { R Square } \\
\text { Change }\end{array}$ & $\begin{array}{c}\text { F } \\
\text { Change }\end{array}$ & df1 & df2 & $\begin{array}{c}\text { Sig. F } \\
\text { Change }\end{array}$ \\
\hline 1 & $.546^{\mathrm{a}}$ & 0.298 & 0.295 & 7.50037 & 0.298 & 93.856 & 1 & 221 & 0.000 \\
\hline
\end{tabular}

a. Predictors: (Constant), VLT

b. Dependent Variable: TOEFL reading subtest

The explained variance of vocabulary knowledge is 0.274 in IELTS reading subtest and 0.298 in TOEFL reading subtest. The latter is 0.024 higher. However, the results on both tests show that vocabulary breadth has a good prediction of reading in both IELTS and TOEFL.

Table 7. Coefficients.

\begin{tabular}{ccccccc}
\hline \multirow{2}{*}{ Model } & \multicolumn{2}{c}{$\begin{array}{c}\text { Unstandardized } \\
\text { Coefficients }\end{array}$} & $\begin{array}{c}\text { Standardized } \\
\text { Coefficients }\end{array}$ & t & Sig. \\
\cline { 3 - 5 } & B & Std. Error & Beta & & \\
\hline \multirow{2}{*}{1} & (Constant) & 7.797 & 2.405 & & 3.243 & .001 \\
& VLT & 0.297 & 0.031 & 0.546 & 9.688 & .000 \\
\hline
\end{tabular}

a. Predictors: (Constant), VLT

b. Dependent Variable: TOEFL reading subtest 
Is`hata Akbarian and Seyyed Mohammad Alavi Comparing the Contribution of Vocabulary...

In like manners we further tried to understand the percentage of increase in the independent variable and the resultant change in the dependent variable. Table 7 shows that we obtained $a=7.797$ for the intercept and $b=0.297$ for the slope. So, given the data, for each percentage of increase in VLT scores, the percentage of increase in the scores on the reading subsection of TOEFL goes higher by $b(0.297)$ units. The higher percentage of the unit of slope in this equation indicates that VLT has more predictive power in TOEFL reading subtest in comparison with that of IELTS.

We now turn to analyzing the collected data with regard to the overall performance of the participants on VLT and their performance on its four levels of word frequency bands. In order to investigate the performance of the participants with different levels of vocabulary proficiency on the reading subtests of IETLS and TOEFL, it was decided to group the participants into levels of vocabulary knowledge, taking into account the performance of the participants on the frequency bands of VLT. So grouping was done based on the participants' percentile rank for the scores they obtained on VLT. A learner's percentile rank shows how well he or she performs on a test in comparison to the others. On that basis, it was decided to have percentiles for six equal groups, but then we converted the six groups into three for the reason that will be discussed below Table 8 . The minimum obtained score on VLT was 32 and the maximum one was 119 . Table 8 shows the percentiles and the scores falling in the interval between the respective lower and the upper percentiles:

Table 8. Percentiles and Scores in the Respective Intervals on VLT.

\begin{tabular}{ccccccc}
\hline \multicolumn{1}{c}{} & \multicolumn{1}{c}{} & & & \\
\hline Percentile & $16.67^{\text {th }}$ & $33.33^{\text {th }}$ & $50^{\text {th }}$ & $66.67^{\text {th }}$ & $83.33^{\text {th }}$ & $100^{\text {th }}$ \\
\hline Score & $32-56$ & $57-67$ & $68-76$ & $77-84$ & $85-94$ & $95-119$ \\
\hline
\end{tabular}

The cut-off score for passing any of the four levels of the frequency words is 24 . It means that a learner scoring 24 at any level has almost mastered the most frequent 1,000 words of that particular level. This assertion implies that a respondent acquiring one level of VLT has also mastered the other levels lying beneath it.

It is not reasonable to expect a language learner mastering the first most frequent 1,000 words to attempt the reading subtests of IELTS and TOEFL. As a result, care was exercised to take the second and forth percentile rank as the cut point for grouping and thus we divided the participants into three groups:

- Group 1 (henceforth, low group) with the percentile rank of $33.33^{\text {th }}$ includes obtained scores from 32 to 67 , i.e., including the first and the third most frequent 1,000 words of VLT under one joint level.

- Group 2 (henceforth, middle group) with the percentile rank of $66.67^{\text {th }}$ includes obtained scores from 68 to 84 .

- Group 3 (henceforth, high group) includes scores falling above the percentile rank of $66.67^{\text {th }}$, i.e. the obtained score 85 and above.

The descriptive statistics in Table 9 and 10 provide a general profile of the data with respect to proficiency levels based on percentile ranking. A quick inspection of the tables 
indicates that the mean on both IELTS and TOEFL reading subtests increases across low, middle, and high groups on VLT. The implication is that vocabulary knowledge might explain different amounts of shared variance for each of these three groups. To explain for the increase on the mean of the scores on IELTS, the predictive values of VLT in terms of these three groups in accounting for the variance in IELTS reading subtest were investigated further in a series of linear regression analyses (Table 11 and 12).

As Table 11 reports, a weak relationship exists between IELTS reading subtest and VLT for the low group and high group, $\mathrm{R}=0.350,0.361$, respectively. The respective corresponding coefficients of determination (adjusted $\mathrm{R}^{2}$ ) are reported as 0.123 and 0.130 . But no significant relationship is reported for the results of the middle group between these two variables.

Table 9. Descriptive Statistics for the Reading Subtest of IELTS and Percentile Levels of VLT.

\begin{tabular}{ccccc}
\hline & MPS & Mean & Std. Deviation & N \\
\hline IELTS reading subtest & 40 & 18.70 & 4.32 & 60 \\
\hline VLT low group & 67 & 57.33 & 8.06 & 60 \\
\hline IELTS reading subtest & 40 & 22.76 & 5.65 & 75 \\
\hline VLT middle group & 84 & 75.99 & 4.70 & 75 \\
\hline IELTS reading subtest & 40 & 26.01 & 6.19 & 67 \\
\hline VLT high group & 119 & 95.10 & 8.06 & 67 \\
\hline
\end{tabular}

Note: $M P S=$ Maximum Possible Score

Table 10. Descriptive Statistics for the Reading Subtest of TOEFL and Percentile Levels of VLT.

\begin{tabular}{ccccc}
\hline & MPS & Mean & Std. Deviation & N \\
\hline TOEFL reading subtest & 50 & 24.59 & 7.87 & 69 \\
\hline VLT low group & 67 & 58.03 & 7.51 & 69 \\
\hline TOEFL reading subtest & 50 & 31.10 & 7.20 & 83 \\
\hline VLT middle group & 84 & 76.17 & 4.83 & 83 \\
\hline TOEFL reading subtest & 50 & 35.79 & 8.30 & 71 \\
\hline VLT high group & 119 & 95.41 & 8.58 & 71 \\
\hline
\end{tabular}

Note: $M P S=$ Maximum Possible Score

Table 11. Model Summary for IELTS and VLT Based on Percentile Groups.

\begin{tabular}{|c|c|c|c|c|c|c|c|c|c|c|}
\hline \multirow[b]{2}{*}{ VLT } & \multirow[b]{2}{*}{$\frac{\bar{d}}{2}$} & \multirow[b]{2}{*}{$\mathbf{R}$} & \multirow[b]{2}{*}{$\begin{array}{c}\text { R } \\
\text { Square }\end{array}$} & \multirow[b]{2}{*}{$\begin{array}{c}\text { Adjusted } \\
\text { R } \\
\text { Square }\end{array}$} & \multirow{2}{*}{$\begin{array}{c}\text { Std. } \\
\text { Error of } \\
\text { the } \\
\text { Estimate }\end{array}$} & \multicolumn{5}{|c|}{ Change Statistics } \\
\hline & & & & & & $\begin{array}{c}\text { R } \\
\text { Square } \\
\text { Change }\end{array}$ & $\begin{array}{c}\text { F } \\
\text { Change }\end{array}$ & Df1 & df2 & $\begin{array}{c}\text { Sig. F } \\
\text { Change }\end{array}$ \\
\hline Low & 1 & $0.350^{\mathrm{a}}$ & 0.123 & 0.108 & 4.08381 & 0.123 & 8.113 & 1 & 58 & 0.006 \\
\hline Middle & 1 & $0.066^{\mathrm{a}}$ & 0.004 & -0.009 & 5.67804 & 0.004 & 0.315 & 1 & 73 & 0.576 \\
\hline High & 1 & $0.361^{\mathrm{a}}$ & 0.130 & 0.117 & 5.81651 & 0.130 & 9.752 & 1 & 65 & 0.003 \\
\hline
\end{tabular}

a. Predictors: (Constant), VLT at low, middle, and high levels

b. Dependent Variable: IELTS reading subtest 
Is`hata Akbarian and Seyyed Mohammad Alavi Comparing the Contribution of Vocabulary...

Table 12 reports the intercepts and the slopes for the low, middle, and high group of the participants in our study. Thus, for each percentage or point of increase in VLT at each level of these three groups, the percentage of scores on IELTS reading subtest increases by $b$ units accordingly.

Table 12. Coefficients.

\begin{tabular}{ccccccc}
\hline \multirow{2}{*}{ Model } & \multicolumn{2}{c}{$\begin{array}{c}\text { Unstandardized } \\
\text { Coefficients }\end{array}$} & $\begin{array}{c}\text { Standardized } \\
\text { Coefficients }\end{array}$ & t & Sig. \\
\cline { 3 - 5 } & & B & Std. Error & Beta & & \\
\hline \multirow{2}{*}{1} & (Constant) & 7.926 & 3.819 & & 2.075 & 0.042 \\
& VLT low group & 0.188 & 0.066 & 0.350 & 2.848 & 0.006 \\
\hline \multirow{2}{*}{1} & (Constant) & 16.768 & 10.697 & & 1.568 & 0.121 \\
& VLT middle group & 0.079 & 0.141 & 0.066 & 0.561 & 0.576 \\
\hline \multirow{2}{*}{1} & (Constant) & -0.377 & 8.481 & & -0.044 & 0.965 \\
& VLT high group & 0.278 & 0.089 & 0.361 & 3.123 & 0.003 \\
\hline
\end{tabular}

a. Predictors: (Constant), VLT at low, middle, and high levels

b. Dependent Variable: IELTS reading subtest

Likewise, the predictive values of VLT in terms of these three groups in explaining the variance in TOEFL reading subtest were also investigated further in a series of linear regression analyses (Table 13 and 14). As Table 13 reports, there is no significant relationship between VLT and the reading subtest of TOEFL for the low and middle group of participants. However, for the high group, the relationship reported is moderate $(\mathrm{R}=457, p$ $<.01$ ). Therefore, more than 20 per cent of the shared variance (adjusted $\mathrm{R}^{2}$ ) in the reading subtest of TOEFL is accounted for by vocabulary knowledge alone for the high group.

Table 13. Model Summary for TOEFL and VLT Based on Groups.

\begin{tabular}{|c|c|c|c|c|c|c|c|c|c|c|}
\hline \multirow[b]{2}{*}{ VLT } & \multirow[b]{2}{*}{ 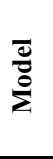 } & \multirow[b]{2}{*}{$\mathbf{R}$} & \multirow[b]{2}{*}{$\begin{array}{c}\mathbf{R} \\
\text { Square }\end{array}$} & \multirow[b]{2}{*}{$\begin{array}{c}\text { Adjusted } \\
\text { R } \\
\text { Square }\end{array}$} & \multirow{2}{*}{$\begin{array}{c}\text { Std. } \\
\text { Error of } \\
\text { the } \\
\text { Estimate }\end{array}$} & \multicolumn{5}{|c|}{ Change Statistics } \\
\hline & & & & & & $\begin{array}{c}\text { R } \\
\text { Square } \\
\text { Change }\end{array}$ & $\begin{array}{c}F \\
\text { Change }\end{array}$ & Df1 & df2 & $\begin{array}{c}\text { Sig. F } \\
\text { Change }\end{array}$ \\
\hline Low & 1 & $0.104^{\mathrm{a}}$ & 0.011 & -0.004 & 7.88432 & 0.011 & 0.736 & 1 & 67 & 0.394 \\
\hline Middle & 1 & $0.163^{\mathrm{a}}$ & 0.027 & 0.015 & 7.14893 & 0.027 & 2.222 & 1 & 81 & 0.140 \\
\hline High & 1 & $0.457^{\mathrm{a}}$ & 0.209 & 0.198 & 7.43879 & 0.209 & 18.246 & 1 & 69 & 0.000 \\
\hline
\end{tabular}

a. Predictors: (Constant), VLT at low, middle, and high levels

b. Dependent Variable: TOEFL reading subtest 
Similar to IELTS reading subtest, the percentage or point of scores on TOEFL reading subtest increases by $b$ units for each percentage or point of increase in VLT for each of these three groups in proportion to their vocabulary proficiency levels (Table 14).

Table 14. Coefficients.

\begin{tabular}{ccccccc}
\hline \multirow{2}{*}{ Model } & \multicolumn{2}{c}{$\begin{array}{c}\text { Unstandardized } \\
\text { Coefficients }\end{array}$} & $\begin{array}{c}\text { Standardized } \\
\text { Coefficients }\end{array}$ & \multirow{2}{*}{ t } & Sig. \\
\cline { 3 - 6 } & & B & Std. Error & Beta & & \\
\hline \multirow{2}{*}{1} & (Constant) & 18.255 & 7.450 & & 2.450 & 0.017 \\
& VLT low group & 0.109 & 0.127 & 0.104 & 0.858 & 0.394 \\
\hline \multirow{2}{*}{1} & (Constant) & 12.523 & 12.485 & & 1.003 & 0.319 \\
& VLT middle group & 0.244 & 0.164 & 0.163 & 1.491 & 0.140 \\
\hline \multirow{2}{*}{1} & (Constant) & -6.460 & 9.930 & & -0.651 & 0.518 \\
& VLT high group & 0.443 & 0.104 & 0.457 & 4.272 & 0.000 \\
\hline
\end{tabular}

a. Predictors: (Constant), VLT at low, middle, and high levels

b. Dependent Variable: TOEFL reading subtest

Overall, 202 participants answered IELTS reading subtest and 223 participants responded to TOEFL reading subtest. However, as Table 15 shows, only 188 of these participants were able to take both IELTS and TOEFL reading subtests. Table 15 also shows the descriptive statistics for VLT and the reading subtests of IELTS and TOEFL. With 188 participants for the two tests, the respective correlations and effect sizes are 0.495 and 0.245 between VLT and IELTS reading subtest, and 0.570 and 0.325 between VLT and TOEFL reading subtest (Table 16). The effect sizes show one more time that VLT has a slightly more predictive role in TOEFL reading subtest, i.e. there is 0.08 per cent higher shared variance between VLT and TOEFL reading subtest.

Table 15. Descriptive Statistics for VLT and Reading Subtests of IELTS and TOEFL.

\begin{tabular}{ccccc}
\hline & MPS & Mean & Std. Deviation & N \\
\hline IELTS reading subtest & 40 & 22.90 & 6.17 & 188 \\
\hline TOEFL reading subtest & 50 & 31.93 & 7.80 & 188 \\
\hline VLT & 120 & 77.12 & 16.04 & 188 \\
\hline
\end{tabular}

Note: $M P S=$ Maximum Possible Score 
Is `haAq Akbarian and Seyyed Mohammad Alavi Comparing the Contribution of Vocabulary...

Table 16. Correlations and Effect Sizes for VLT and Reading

Subtests of IELTS and TOEFL.

\begin{tabular}{ccccc}
\hline & \multicolumn{3}{c}{ VLT } \\
\cline { 2 - 4 } & $\mathbf{R}$ & $\mathbf{R}^{\mathbf{2}}$ & Sig. \\
\hline IELTS & 0.495 & 0.245 & 0.000 \\
\hline TOEFL & 0.570 & 0.325 & 0.000 \\
\hline
\end{tabular}

As to the performance on both IELTS and TOEFL reading subtests across groups, the descriptive statistics in Table 17 provide a general profile of the data and Table 18 shows the correlations and the effect sizes of the three groups with different vocabulary proficiency levels.

Table 17. Descriptive Statistics for VLT and Reading Subtests of IELTS and TOEFL.

\begin{tabular}{ccccc}
\hline & MPS & Mean & Std. Deviation & N \\
\hline IELTS reading subtest & 40 & 19.20 & 4.05 & 54 \\
\hline TOEFL reading subtest & 50 & 26.41 & 5.93 & 54 \\
\hline VLT low group & 67 & 58.06 & 8.06 & 54 \\
\hline IELTS reading subtest & 40 & 22.83 & 5.76 & 72 \\
\hline TOEFL reading subtest & 50 & 32.07 & 6.50 & 72 \\
\hline VLT middle group & 84 & 76.10 & 4.76 & 72 \\
\hline IELTS reading subtest & 40 & 26.21 & 6.37 & 62 \\
\hline TOEFL reading subtest & 50 & 36.56 & 7.62 & 62 \\
\hline VLT high group & 119 & 94.92 & 8.23 & 62 \\
\hline
\end{tabular}

Note: $M P S=$ Maximum Possible Score

Table 18. Correlations and Effect Sizes for VLT and Reading Subtests of IELTS and TOEFL across Groups.

\begin{tabular}{ccccc|ccc|cccc}
\hline & \multicolumn{3}{c|}{ Low Group } & \multicolumn{3}{c|}{ Middle Group } & \multicolumn{3}{c}{ High Group } \\
\cline { 2 - 12 } Reading Subtest & \multicolumn{3}{c|}{ VLT } & \multicolumn{3}{c|}{ VLT } & \multicolumn{3}{c}{ VLT } \\
\cline { 2 - 12 } & $\mathbf{R}$ & $\mathbf{R}^{\mathbf{2}}$ & Sig. & $\mathbf{R}$ & $\mathbf{R}^{\mathbf{2}}$ & Sig. & $\mathbf{R}$ & $\mathbf{R}^{\mathbf{2}}$ & Sig. \\
\hline IELTS & 0.240 & 0.058 & 0.040 & 0.060 & 0.004 & 0.309 & 0.378 & 0.143 & 0.001 \\
\hline TOEFL & 0.180 & 0.032 & 0.096 & 0.115 & 0.013 & 0.169 & 0.450 & 0.203 & 0.000 \\
\hline
\end{tabular}

Note: Sig. $=$ Sig. $(1$-tailed $), R=$ correlation, and $R^{2}=$ effect size 
Table 18 shows that there is a significant, but weak, correlation between VLT and IELTS reading subtest for low group, and there is a significant relationship between VLT and the reading section of IELTS and TOEFL for high group. The effect sizes reported for high group show more predictive role of VLT in TOEFL reading subtest, however. It seems that the necessity of knowing 5,000 word families as the threshold for having an adequate understanding of the passage content is confirmed by the results in this investigation.

\section{Discussion}

This research focuses on whether vocabulary breadth provides more contribution to the reading subtest of IELTS or TOEFL. The first set of data analyses was reported on VLT and IELTS reading subtest above, showing a significant and moderate correlation between the two tests. This finding corroborates the result obtained by Milton, Wade, and Hopkins (2010) who found a strong relationship between a vocabulary breadth test and IELTS reading component. Our results also show that there is a significantly moderate relationship between VLT and TOEFL reading subtest, thus being in line with Qian $(1999,2002)$. Generally speaking, the results on both tests so far support the contention that vocabulary knowledge has a predictive role in reading comprehension (Qian, 1999, 2002; Zhang \& Anual, 2008).

The second set of data analyses concerns the results across groups that are worth noting. There is a significant correlation between VLT and IELTS reading subtest for low and high group whereas no significant relationship was observed between the two tests for middle group. How is it that there is a predictive relationship between vocabulary proficiency and the reading comprehension of IELTS for the participants in low group and high group, but not for the participants in middle group? The participants in middle group have passed the threshold of 3,000 most frequent words and even know more words than the participants in low group do. But it seems that they do not rely much on vocabulary knowledge in reading comprehension of IELTS. Apparently, the other knowledge sources are helpful to this group in comprehending IELTS reading subtest. Another interpretation might be that the participants in middle group have not developed a lot of vocabulary knowledge so as to perform well on reading comprehension. Inspecting the obtained scores (Table 8), lying in the interval between percentile scores, reveals some important points in relation to vocabulary growth and distribution of scores around the mean on VLT; the minimum obtained score and the maximum obtained score on VLT are 32 and 119, respectively and the mean on VLT is 77 (rounded). Logically, in normally distributed scores, the obtained scores will cluster around the mean. So the conclusion is that the range of obtained scores within an interval farther from the mean is larger than the range of the obtained scores in the intervals adjacent to the mean. Table 8 shows the range of obtained scores in the interval between the six percentile ranks as $24,10,8,7,9$, and 34 . Three percentile ranks were selected for dividing the participants into three groups with the following range of the scores falling in their intervals: 35,16 , and 34 . The participants in middle group had a range of 16 points. If we remember that the lowest score was 68 and the highest 84, then it indicates that the participants falling within this interval of obtained scores might know around 4,000 most frequent words. If this is the case, then a low increase of the mean on IELTS reading subtest is justifiable. The participants at this level have not improved their vocabulary proficiency so much so as to perform better on reading comprehension. 
Is`hata Akbarian and Seyyed Mohammad Alavi Comparing the Contribution of Vocabulary...

Table 12 shows these issues very clearly. As displayed, for one standard deviation of change in the variable of vocabulary knowledge in middle group, there is a change of 0.066 of a standard deviation in the performance on IELTS reading subtest, i.e. vocabulary breadth contributes less to IELTS reading subtest. The change is much higher for low and high group. In these groups, for one standard deviation of change in the variable of vocabulary knowledge, there is respectively a change of 0.350 and 0.361 of a standard deviation in the performance on IELTS reading subtest. In other words, vocabulary breadth contributes more to IELTS reading subtest. The small increase on the predicted score in IELTS reading subtest for middle group is a good evidence for the important role of vocabulary knowledge in reading comprehension in general and IELTS reading subtest in particular.

The results reported in the reading subtest of TOEFL (Table 13 and 14) indicate a different story. There is no significant relationship for low and middle groups. However, the participants in high group, correctly answering 80 per cent of the items at the 5,000 level of word frequency on VLT, seem to benefit more from vocabulary knowledge in answering reading comprehension items on TOEFL. There is a moderate relationship between the two variables of vocabulary breadth and reading comprehension, $\mathrm{R}=0.457$. If we square this correlation to see how much of the variance it accounts for, then one conclusion should be that vocabulary breadth alone accounts for about 0.209 of the factors involved in the reading comprehension of TOEFL. When we think of all the other factors that could be involved in reading comprehension grammatical knowledge, knowledge of discourse, background knowledge, an understanding of how texts are organized, skill in reading, writing, etc., and fluency then 20.9 per cent shared variance for vocabulary knowledge alone is very substantial. It is interesting to note that the accounted variance in TOEFL reading subtest is 0.079 higher than that of IELTS reading subtest for the participants in high group. One reason might be the existence of an item that measures guessing the meaning of vocabulary from contextual information in the edition of TOEFL reading subtest that was administered in our study. Or it might be due to the fact that IELTS reading is more task-based in comparison to TOEFL reading.

In addition, our findings across groups indirectly support the first line of research that links a connection between the percentage of running words in a text and reading comprehension (Hu \& Nation, 2006; Nation, 2006). That is, the more vocabulary the readers know, the more running words in a text will be familiar to them. This proficiency, in turn, leads to a better processing and comprehension of texts. Since the passages in IELTS and TOEFL reading cover a range of texts, some of which are more or less similar to those found in novels and newspapers, then here it might seem proper to link the outcome of our study to a number of the other findings by the recent study of Nation (2006), referred to in the review of literature. This authority on vocabulary research estimates that a vocabulary of 8,000 to 9,000 words is needed to read a novel, and even then, 1 word in 50 will be unfamiliar and that the 2,000 most frequent words in the $\mathrm{BNC}$ account for about $83 \%$ of the running words in newspapers. Also the most common 4,000 words plus proper nouns account for about $95 \%$ of the running words in a page of a newspaper. Thus, to gain an unassisted comprehension of newspapers, i.e. $98 \%$ coverage, a vocabulary of at least 8,000 words plus proper nouns is needed (Nation, 2006: 71). Consequently, only our high group might resort less to dictionaries and might encounter less frustration in trying to gain an unassisted comprehension in reading newspapers or novels. 
Similarly, the results across groups also support what Nation and Waring (1997) stated over a decade ago. They argue that a small number of English words, such as the, occur very frequently and knowing them equals to knowing a very large proportion of the running words in a written or spoken text. Since most of such words are content words, therefore knowing enough of them leads to a good degree of comprehension of a text.

A further confirmation of our results across groups comes from the finding by Golkar and Yamini (2007) who argue that vocabulary size is highly correlated with both proficiency level and reading comprehension ability.

The final set of analyses conducted is concerned with comparing whether IELTS reading subtest or TOEFL reading subtest was more related to VLT. Remember that only 188 of all the participants had taken both IELTS and TOEFL reading subtests. Once the performance of these participants taking both tests is evaluated, once again it emerges that VLT has a more predictive relationship with the reading subtest of TOEFL in comparison with that of IELTS. This high predictive value in the case of TOEFL reading subtest might, as discussed earlier, be attributed to the point that the TOEFL reading subtest under study includes a number of reading comprehension items on guessing the meaning of unknown words from the information existing in the context and co-text. However, IELTS reading subtest that was administered in this study does not include any such items that are directly related to assessing the meaning of unknown vocabulary from the available information in the context. Therefore, vocabulary knowledge plays a different role in the reading subsection of either of the two tests.

All this calls for putting vocabulary knowledge as the priority in language learning programs since Laufer and Yano (2001: 549) state that, in academic settings, second language learners and similarly EFL learners are expected to handle a vast amount of reading materials intended for native speakers. But their vocabulary knowledge does not amount to a quarter of the vocabulary known by their native speaking peers. Second language or EFL learners might be placed at a desperate position by not putting vocabulary knowledge as the priority.

\section{Conclusion}

In this study, it is shown that vocabulary breadth is more related to the reading subtest of TOEFL in comparison with that of IELTS. However, the results obtained suggest that it does not make much difference which test is more associated with vocabulary breadth. Rather, the evidence suggests that vocabulary breadth is crucially important in reading comprehension in general, and in the reading subtest of both IELTS and TOEFL in particular, for the participants in this research, studying in different Iranian universities. The findings of our study might be generalized to other EFL learners in case there is more replication of this investigation with similar results.

\section{ACKNOWLedgements}

Sincere thanks are due to all the participants for generously sitting long hours to answer our tests. 
Is`hata Akbarian and Seyyed Mohammad Alavi Comparing the Contribution of Vocabulary...

\section{REFERENCES}

Akbarian, I. (2010). Review of the book Vocabulary and Writing in a First and Second Language: Processes and Development, in English for Specific Purposes, 29, 1: 215-217.

Alavi, S. M., and Akbarian, I. (2012). The role of vocabulary size in predicting performance on TOEFL reading item types, in System, 40, 3: 376-385.

Cambridge IELTS 5, Examination Papers from University of Cambridge ESOL Examinations: English for Speakers of Other Languages. (2006). Cambridge: Cambridge University Press.

Golkar, M., and Yamini, M. (2007). Vocabulary, proficiency and reading comprehension, in The Reading Matrix, 7, 3: 88-112.

Hu, M., and Nation, I. S. P. (2000). Unknown vocabulary density and reading comprehension, in Reading in a Foreign Language, 13, 2: 403-430.

Laufer, B., and Yano, Y. (2001). Understanding unfamiliar words in a text: Do L2 learners understand how much they don't understand?, in Reading in a Foreign Language 13, 2: 549-66.

Meara, P., and Milton, J. (2003). X_Lex, The Swansea Levels Test. Newbury: Express.

Milton, J. (2009). Measuring Second Language Vocabulary Acquisition. Bristol, England: Multilingual Matters.

Milton, J., and Hopkins, N. (2005). Aural_Lex. Swansea: Center for Applied Language Studies.

Milton, J., Daller, H., Malvern, D., Meara, P., Richards, B., and Treffers-Daller, J. (Eds.). (2008). Guest editorial, in Language Learning Journal, 36, 2: 135/138.

Milton, J., Wade, J. and Hopkins, N. (2010). Aural word recognition and oral competence in English as a foreign language, in R. Chacón-Beltrán, C. Abello-Contesse and M.M. Torreblanca-López (eds.), Insights into Non-native Vocabulary Teaching and Learning. Bristol: Multilingual Matters, 83/98.

Nation, I. S. P. (1983). Testing and teaching vocabulary, in Guidelines, 5, 1: 12-25.

Nation, I. S. P. (1990). Teaching and Learning Vocabulary. New York: Newbury House.

Nation, I. S. P. (2006). How large a vocabulary is needed for reading and listening?, in The Canadian Modern Language, 63, 1: 59-82.

Nation, I. S. P. and Waring, R. (1997). Vocabulary size, text coverage, and word lists, in N. Schmitt and M. McCarthy (eds.), Vocabulary: Description, Acquisition, Pedagogy. New York: Cambridge University Press, 6-19.

Qian, D. (1999). Assessing the roles of depth and breath of vocabulary knowledge in reading comprehension, in The Canadian Modern Language Review, 56, 2: 283-307.

Qian, D. (2002). Investigating the relationship between vocabulary knowledge and academic reading performance: An assessment perspective, in Language Learning, 52, 3: 513-536.

Schmitt, N., Schmitt, D. and Clapham, C. (2001). Developing and exploring the behaviour of two new versions of the Vocabulary Levels Test, in Language Testing, 18, 1: 55-88.

Stæhr, L. S. (2008). Vocabulary size and the skills of listening, reading and writing, in Language Learning Journal, 36, 2: 139-152.

TOEFL Actual Tests. (2005). Tehran: Ebteda Publications.

Zhang, L. J. and Anual, S. B. (2008). The role of vocabulary in reading comprehension: The case of secondary school students learning English in Singapore, in RELC Journal, 39, 1: $51-76$. 